\title{
EFEK INJEKSI PLASMA KAYA PLATELET TERHADAP TENOSINOVITIS TENDON TIBIALIS POSTERIOR: SEBUAH STUDI KASUS
}

(The Effect Of Platelet Rich Plasma Injection On Posterior Tibial Tendon Tenosynovitis: A

Case Report)

Henry Ricardo Handoyo ${ }^{1)}$, Andryan Hanafi Bakri ${ }^{2)}$, Andri Primadhi ${ }^{3)}$

\begin{abstract}
Introduction: Posterior tibial tendon dysfunction is one of the most common, problems of the foot and ankle. Tenosynovitis of the posterior tibial tendon (PTT) is an often unrecognized form of PTT dysfunction. Case: A 54-year-old woman presented with left ankle pain that began while morning walk three days prior. She noted that the left ankle hurt with even light touch and the pain was unrelieved with sodium diclofenac. She denied any history of trauma. She was seen in the outpatient clinic for this condition. On examination, a three centimeter area of pain was found posterior to the medial malleolus and parallel to the PTT. She also had a stage I flat foot and mild soft tissue swelling around medial malleolus region on her radiograph examination. Ultrasound examination was done with the result of anechoic fluid visible in the peritendinous space around the PTT. The patient received diagnosis of PTT tenosynovitis, with the foot and ankle disability index (FADI) score was 58.7. Platelet rich plasma (PRP) injection was done twice with an interlude of two weeks. The pain subsided and the following FADI score was 84.6. Outcome: Patient showed improvement in her left ankle PTT tenosynovitis after two PRP injection. Conclusion: This case report highlights the efficacy of PRP as a modality in managing PTT tenosynovitis.
\end{abstract}

Keywords: Ankle, Flat Foot, Posterior Tibial Tendon, Tenosynovitis, Platelet Rich Plasma.

\begin{abstract}
ABSTRAK
Pendahuluan: Disfungsi tendon tibialis posterior (TTP) mereupakan salah satu problematika yang banyak ditemukan di daerah pergelangan kaki dan kaki. Tenosinovitis TTP merupakan suatu bentuk disfungsi TTP yang sering tidak terdeteksi. Kasus: Seorang wanita berumur 54 tahun datang dengan keluhan nyeri pergelangan kaki kiri yang dirasakan setelah berjalan kaki pada tiga hari sebelumnya. Pasien merasakan nyeri bahkan dengan sentuhan ringan dan tidak membaik dengan konsumsi natrium diklofenak. Adanya riwayat trauma disangkal oleh pasien. Pemeriksaan dilakukan di unit rawat jalan terkait keadaan tersebut. Pada pemeriksaan fisik,
\end{abstract}


area nyeri sebesar tiga sentimeter ditemukan pada posterior maleolus medialis dan paralel terhadap TTP. Adanya flat foot derajat I dan pembengkakan ringan juga ditemukan dalam pemeriksaan radiologi. Pada pemeriksaan ultrasound, didapatkan cairan anekhoik pada daerah peritendinous sekitar TTP. Pasien didiagnosis tenosinovitis TTP, dengan skor foot and ankle disability index (FADI) sebesar 58.7. Injeksi plasma kaya platelet dilakukan sebanyak dua kali dengan interval dua minggu.Keluhan nyeri berkurang dan skor FADI menjadi 84.6. Hasil: Terdapat perbaikan dari tenosinovitis TTP yang dialami pasien pasca $2 \mathrm{x}$ suntikan PRP. Kesimpulan: Studi kasus ini menunjukkan efikasi plasma kaya platelet sebagai sebuah modalitas dalam penanganan tenosinovitis TTP.

Kata Kunci: Pergelangan Kaki, Flat Foot, Tendon Tibialis Posterior, Tenosinovitis, Plasma Kaya Platelet.

1) Orthopedic surgeon of Surabaya Orthopedic and Traumatology Hospital and Faculty of Medicine of Widya Mandala Catholic University, Jl. Kalisari Selatan 1, Pakuwon City, Surabaya, Indonesia, Email : henryricardohandoyo@gmail.com

2) General practitioner of Surabaya Orthopedic and Traumatology Hospital, Indonesia

3) Orthopedic surgeon of Dr. Hasan Sadikin General Hospital, Bandung, Indonesia

\section{INTRODUCTION}

Posterior tibial tenosynovitis is a degenerative disorder involving posterior tibial tendon (PTT), of which has precarious blood supply ${ }^{1,2,3}$. Despite current advance in imaging technology, it is easily overlooked, thus leads to progression of the disorder that could end up to deformity of the foot. Therefore, early detection followed by prompt intervention is crucial to halt its progression ${ }^{2,3}$. In the early stage of the disorder, conservative approaches including analgesics, physiotherapy to various orthotics are preferred to surgical treatment ${ }^{1,2}$. While the use of analgesics, including NSAIDs, is not without side effects, platelet rich plasma (PRP) injection is gaining popularity in the past few years.
Its anti-inflammatory effect with few side effect is considered as breakthrough in managing various orthopedics problems, including soft tissue disorders ${ }^{4,5}$. Albeit, there is still limited specific study highlighting the effectiveness of PRP as posterior tibial tenosynovitis treatment. Therefore, we present a case report of a patient who received PRP injection for the management of her posterior tibial tenosynovitis.

\section{CASE DESCRIPTION}

A 54-year-old woman presented at the orthopedic clinic of Surabaya Orthopedic and Traumatology Hospital with left medial ankle pain, which she had experienced since 3 days prior after morning walk. She found her left ankle 
painful even with light touch, and it was not relieved with sodium diclofenac. Any history of trauma was denied by the patient. On physical examination, the patient appeared to be overweight with body mass index (BMI) of $24.05 \mathrm{~kg} / \mathrm{m}^{2}$ and a three centimeter area of pain was found posterior to medial malleolus and parallel to the PTT alongside a stage I flat foot.

The imaging studies of left ankle were obtained. Spurring of calcaneal, mild blurring of posterior ankle pad and mild soft tissue swelling around medial malleolus region were seen on the left ankle plain radiograph (Figure 1\&2). Meanwhile, USG of left ankle by using Esaote® with 6-12 $\mathrm{MHz}$ frequency of La 523 probe revealed the acute and chronic posterior tibial tenosynovitis at the level of retromalleolar and inframalleolar region alongside loculated fluid collection seen in the medial ankle joint (Figure 3\&4).

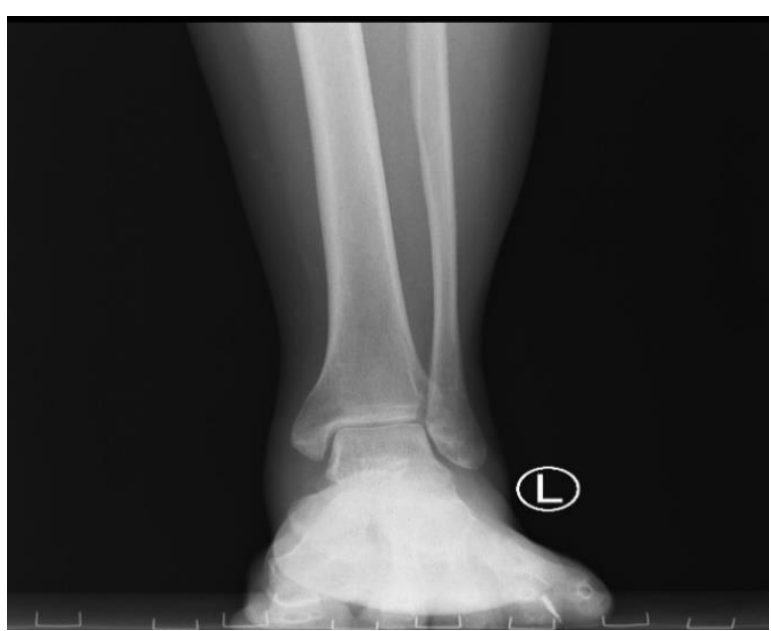

Figure 1. AP view of left ankle

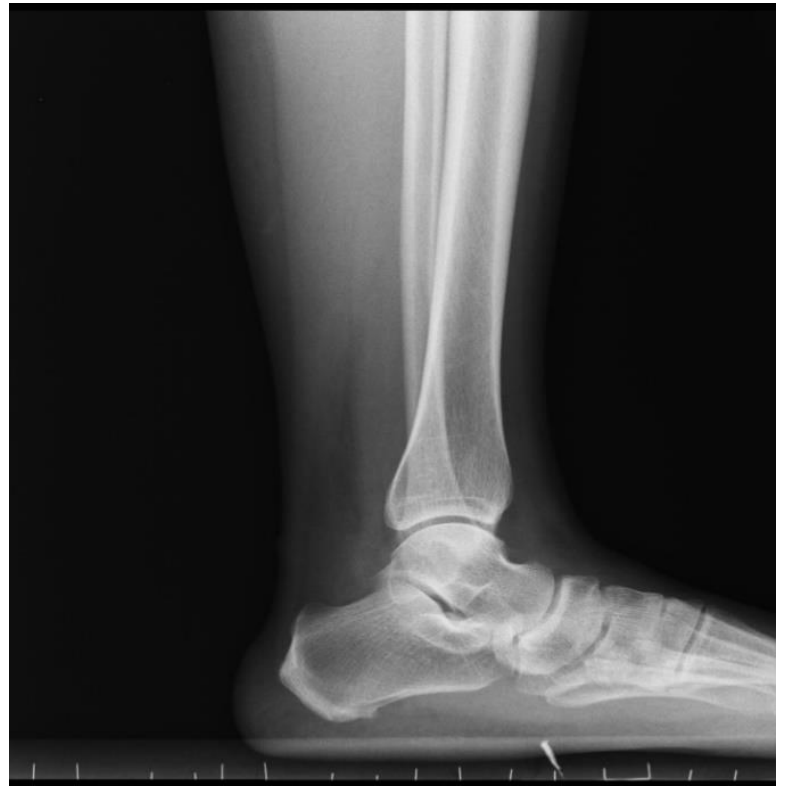

Figure 2. Lateral view of left ankle

Based on those findings, USG guided PRP injection was arranged and the Foot and Ankle Disability Index (FADI) score was chosen as the tool for evaluating patient's response to the therapy. The pre injection FADI score was 58.7 and after receiving 2 PRP injections with 2 weeks interlude, the patient was re-evaluated. The left ankle pain was subsided and the subsequent FADI score was 84.6, which reflected the improvement in her left ankle complaint. 


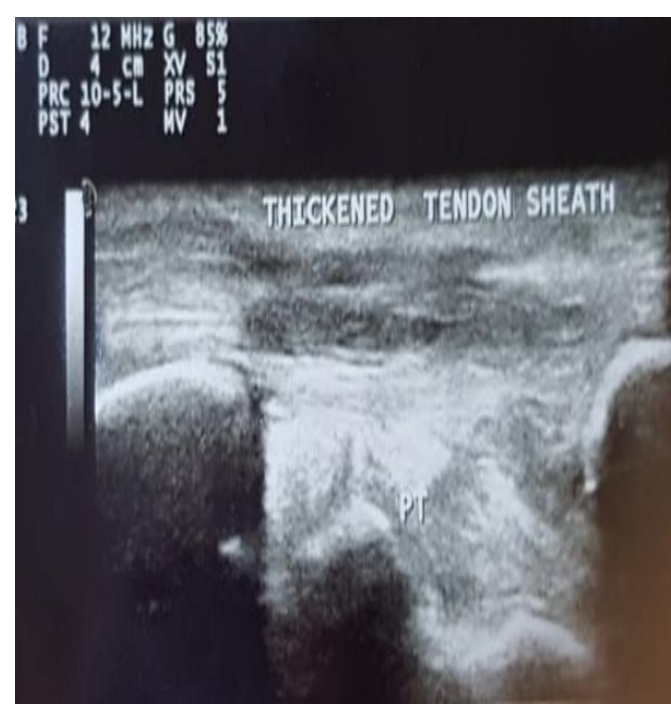

Figure 3. USG depicting PTT tenosynovitis

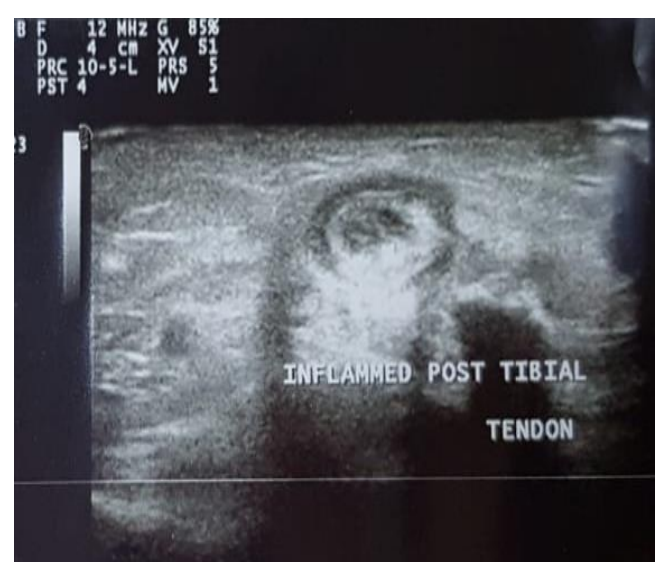

Figure 4. USG depicting PTT tenosynovitis

\section{DISCUSSION}

Posterior tibial tenosynovitis is a degenerative disorder which commonly afflicts obese, middle-aged woman. Overused tendon, age, seronegative spondyloarthropathy and rheumatoid arthritis are some possible causing factors. Our patient in typically reflected the classical posterior tibial tenosynovitis patient. During physical examination, the medial posterior-malleolar pain on palpation alongside positive one leg raise test had made our suspicion of posterior

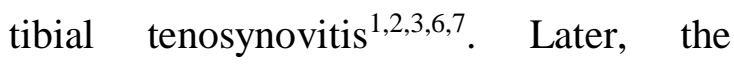
diagnosis was confirmed by USG examination by the appearance of anechoic fluid visible in the peritendinous space around the PTT. Lately, the USG examination has gained popularity as diagnosing tool of posterior tibial tenosynovitis because it is inexpensive and relatively easy to be performed by trained professionals $^{8,9,10}$.

After the diagnosis was confirmed, the stage of PTT dysfunction has to be made in order to choose the right treatment. There are 3 stages of PTT dysfunction, and our patient fitted the criteria for stage 2 PTT due to the inflammatory signs and flattening of medial arch which were found during the physical examination ${ }^{1,2,3}$. Even though some authors suggest the surgical management, the non-operative approach such as the use of walking cast, orthotics as well as the pharmacologic still could be trialed in this stage. Thus, our consideration was to subdue the inflammation of PTT by using the PRP injection. The PRP is a volume of plasma containing higher concentration of platelet compared to blood base line and contains growth factors alongside plasma proteins. The use of PRP injection in managing soft tissue disorders has been found to have positive results, as some studies revealed the efficacy of PRP 
as treatment for lateral epicondylitis, patellar tendinopathy and achilles tendinopathy ${ }^{4,5,11,12}$. In our case report, the PRP injection showed the improvement in patient's posterior tibial tenosynovitis, as shown in increase of FADI score during the interval of 2 weeks. Nevertheless, we didn't find the evidence supporting the use of PRP in managing posterior tibial tenosynovitis. Thus, we strongly recommend further studies to be conducted.

\section{CONCLUSION}

A case report showed the efficacy of PRP injection in managing posterior tibial tenosynovitis. However, further studied should be conducted before establishing it as an alternative in managing stage 2 of posterior tibial tenosynovitis.

\section{INFORMED CONSENT}

The informed consent was obtained from the patient for publication of this case.

\section{REFERENCES}

1. Ling SK, Lui TH. Posterior tibial tendon dysfunction: an overview. Open Othop J. 2017; 11: 714-23.

2. Bubra PS, Keighley G, Rateesh S, Carmody D. Posterior tibial tendon dysfunction: an overlooked cause of foot deformity. J Family Med Prim Care. 2015; 4(1): 26-9.

3. Guelfi M, Pantalone A, Mirapeix RM, Vanni D, Usuelli FG, Guelfi
M, et al. Anatomy, pathophysiology and classification of posterior tibial tendon dysfunction. Eur Rev Med Pharmacol Sci. 2017; 21:13-9.

4. Hussain N, Johal H, Bhandari M. An evidence-based evaluation on the use of platelet rich plasma in orthopedics - a review of the literature. SICOT J. 2017; 5: 57.

5. Niewczas P, Kotela A, Legosz P, Kotela KP, Sarzynska S, Starczynska M. Use of platelet-rich plasma in orthopaedics and traumatology. $\quad$ Medical Studies/Studia Medyczne. 2016; 32(1): 63-8.

6. Durrant B, Chockalingam N, Richards PJ, Roberts CM. Posterior tibial tendon dysfunction: what does the single heel raise test mean in assessment. Foot Ankle Int. 2015; 8(2): 6 .

7. Bare AA, Haddad SL. Tenosynovitis of the posterior tibial tendon. Foot Ankle Clin. 2001; 6(1): 37-66.

8. Drakonaki EE, Allen GM, Watura R. Ultrasound-guided intervention in the ankle and foot. Br J Radiol. 2016; 89: 20150577.

9. Trouilloud AL. The tibialis posterior tendon. J Ultrasound. 2012; 15: 2-6. 
10. Bellew SD, Colbenson KM, Bellamkonda VR. Posterior tibial tendon tenosynovitis diagnosed by point-of-care ultrasound. Clin Pract Cases Emerg Med. 2017; 1(4): 43940.

11. Zhou Y, Wang JHC. PRP treatment efficacy for tendinopathy: a review of basic science studies. Biomed Res Int. 2016; 9103792.

12. Limaye R. Posterior tibial tendon dysfunction and treatment of stage II disease (internet). Leeds: Barker Brooks Communications Ltd; 2017 (2017 Nov 1; cited 2019 Feb 14). Available from: http://www.opnews.com/2017/11/p osterior-tibial-tendon-dysfunctiontreatment-stage-ii-disease/14079 